\title{
Research on Target Enterprise Value Evaluation Based on EVA Model - SEB M \& a SUPOR
}

\author{
Liu ShuLiang \\ Economic Management Institute \\ North China Electric Power University (BaoDing) \\ Hebei province, China \\ 1231s1@163.com
}

\author{
WuJing \\ Economic Management Institute \\ North China Electric Power University (BaoDing) \\ Hebei province, China \\ 2296924427@qq.com
}

\begin{abstract}
In recent years, with the rapid development of China's economy and the continuous improvement of the capital market, corporate mergers and acquisitions, asset restructuring and other activities have become active. In the face of China's current active $M \&$ a market, how to reasonably and accurately target enterprise pricing, become the key issues affecting $M \&$ a activities. This paper summarizes the related theory of enterprise merger, analyzes the value assessment of target enterprise in mergers and acquisitions, introduces the main contents and methods of the assessment of the target enterprise value, and use the case to explain in detail the goal value assessment method, but also on the evaluation results and the actual results and the theoretical results are compared and presented some thinking. Therefore, the purpose of this paper is to study, through the acquisition of the target enterprise value decision of enterprises, hoping to provide some new ideas and references for the acquisition of decision makers, scientific guide china's enterprises mergers and acquisitions practice, promote mergers and acquisitions of domestic enterprises to improve efficiency.
\end{abstract}

Keywords-EVA; Enterprise Merger and Acquisition; Value Evaluation; Model Selection

\section{INTRODUCTION}

Under the new policy and new situation, the state-owned enterprises need to reform the shareholding system, introduce the strategic investors, the reorganization of listed companies and other ways to realize the diversification of property rights, and enhance the vitality and competitiveness of enterprises. Foreign capital in China's capital market openness and gradually improve the legal system and gradually improve the good environment, there will be more opportunities for mergers and acquisitions, mergers and acquisitions will gradually become an important form of foreign enterprises to invest in china. ${ }^{[1]}$

In this case, the business enterprise is a special commodity trading is increasingly attracted people's attention, which can accurately assess the value of the company, not only related to the company's merger and acquisition of major trading activities in decision-making, provide the basis for business transactions, become a difficult point of the capital market, but also in practice the work of the enterprise managers and engaged in intermediary business, investment bankers are concerned. If the assessment is not accurate, it is very likely that foreign mergers and acquisitions in the sale of local assets, overseas mergers and acquisitions price unreasonable. So it is very necessary to study the method of evaluating the value of the target enterprise.

\section{THEORETICAL ANALYSIS OF ENTERPRISE MERGER AND ACQUISITION AND EVALUATION METHOD}

\section{A. Mode of $M \& A$}

The takeover agreement is a kind of widely used in our country, it is through the acquisition of the two sides signed the agreement form, determine the number, the acquisition of the target company equity prices, and after the completion of the acquisition of parties holding such matters, and the implementation of existing laws and regulations in the institutional framework. Private placement is a common way of acquisition in the world. It is not publicly available, and is a kind of acquisition mode for the designated investment object. The form of tender offer is a widely adopted form, which is suitable for the purchase of listed companies, which is realized through the stock exchange market. ${ }^{[2]}$

\section{B. The concept of EVA valuation model}

The core idea of EVA is the cost of capital, which is the rate of return on capital investment projects, the promotion of value creation, and the maximum value of shareholder value.

According to the evaluation method of EVA to measure the economic benefits of the enterprise, one should get much profit, two depends on the occupancy level of economic capital, the growth of EVA and the former is proportional, and inversely proportional to the latter, in other words, if you want to improve the operating profit, on the one hand to increase the revenue, on the other hand to reduce the capital occupied, overall operating income rate is higher than the cost of capital, but also can be adjusted from the capital structure, capital investment will be transferred to the project from the high consumption and low capital projects, but also can improve the EVA value. ${ }^{[3]}$

According to the definition of EVA, the formula for calculating the added value of the economy is:

$\mathrm{EVA}=$ net operating profit after tax - capital cost 
The net operating profit after tax NOPAT, the cost of capital is denoted by TC, weighted average cost of capital rate by WACC, the cost of capital is equal to the weighted average cost of capital and the total investment capital, this formula can be rewritten as: $\mathrm{EVA}=\mathrm{NOPAT}-\mathrm{WACC} \times \mathrm{TC}$

$\mathrm{EVA}=($ capital rate of return - capital cost rate $) \times$ capital

$=($ sales margin $\times$ capital turnover rate - capital cost rate $) \times$ capital

Using EVA model to grasp several key aspects: first, although the EVA system of the main data source in the financial statements, but it needs to make some adjustment to the original accounting items; two is in the adjustment is calculated based on the net operating profit after tax and enterprise investment capital; three is according to the capital asset pricing model to calculate the cost of according to the capital and equity capital, equity capital and debt ratio calculated the weighted average cost of all capital enterprises; four is according to the formula EVA.

\section{THE SIGNIFICANCE OF TARGET ENTERPRISE VALUE EVALUATION TO M \& A}

In a certain sense, the pricing problem of the target enterprise directly determines the success or not, and can accurately estimate the value of the target enterprise is the core of the pricing problem. ${ }^{[4]}$ Mainly reflected in three aspects:

(1)From the acquisition program, generally divided into target selection and assessment, planning, implementation of the merger agreement in three stages, the target selection and evaluation is the most important basic aspects of mergers and acquisitions, the core content and the target assessment is the value assessment, it is decided whether the merger feasible prerequisite.

(2)From the merger motivation, enterprise merger and acquisition is generally for achieving synergies management, management, financial, strategic goals, but in theory, as long as the price is reasonable, the transaction is to be sold, so the two sides is the basis to decide whether to deal on the target value evaluation, is also the focus of the negotiations.

(3)From the perspective of investors, mergers and acquisitions hope transaction value favor, but because both investors does not fully grasp the information or deviation of subjective understanding, in the process of mergers and acquisitions, mergers and acquisitions of enterprises need joint enterprises, and after the merger into the target enterprise value evaluation. ${ }^{[5]}$

The three are both independent and interrelated, are indispensable, together constitute the acquisition of enterprise value assessment, the success of the merger and acquisition plays a vital role.

\section{CASE ANALYSIS}

\section{A. Case background}

Chinese SUPOR group company, is a company with a strong family color of private enterprises, the main business is the manufacture of cooking utensils, with the expansion of the company, the group embarked on the road of diversified development, based on the cooker production of small household electrical appliances as the leading business, first established after the development of production, sales, logistics business chain, involving medicine, commerce, marine resources and other areas in the development of the industry, enterprise development situation is optimistic prospect. France Saibo group company, SEB company, is a production of a pressure cooker for international small appliances group, it was born in 1857 , has nearly 1.5 centuries of production history. ${ }^{[6]}$ Along with the deepening of the degree of internationalization, now its business scope has expanded to Europe and Asia continents Austria in most countries and regions, its branches reached more than and 80 , the total number of employees of the company's $\$ 15000$.

\section{B. Using EVA to evaluate the value of SUPOR}

(1) The process of enterprise value evaluation under EVA

According to the net operating profit after tax calculation formula, combined with SUPOR annual report, the specific adjustment of the project and the calculation method is as follows:

(1)First, the net operating profit adjusted to the pretax profit, calculated under the EVA concept of the business income tax, in order to adjust the interest and income tax on the impact of NOPAT.

(2) Non normal operating profit and loss, the data used in this article directly from the annual report, net of non-recurring items and the amount of the table.

(3) Annual extraction of the reserves, is equal to the annual report of the asset impairment in the list of the data in the final number minus the number of the initial period.

(4)Increase the amount of deferred tax credits, deferred income equal to the disclosure of the balance sheet of the final tax liabilities minus the number of initial number. ${ }^{[7]}$

TABLE I. NET PROFIT AFTER TAX

\begin{tabular}{|c|c|c|c|c|}
\hline project & 2006 & 2007 & 2008 & 2009 \\
\hline Net profit & $\begin{array}{c}102210416 \\
.76\end{array}$ & $\begin{array}{c}17193959 \\
8.55\end{array}$ & $\begin{array}{c}236506990.9 \\
6\end{array}$ & $\begin{array}{c}310416756 . \\
65\end{array}$ \\
\hline $\begin{array}{c}+ \text { Interest } \\
\text { expense }\end{array}$ & 17433000 & 468000 & 0 & 0 \\
\hline $\begin{array}{c}\text { + Minority } \\
\text { shareholder } \\
\text { gains and losses }\end{array}$ & $\begin{array}{c}30553865 . \\
98\end{array}$ & $\begin{array}{c}43372357 . \\
61\end{array}$ & 62900962.91 & $\begin{array}{c}44859059.5 \\
9\end{array}$ \\
\hline $\begin{array}{c}+ \text { Impairment of } \\
\text { fixed assets }\end{array}$ & 0 & 0 & 0 & 0 \\
\hline $\begin{array}{l}\text { + Impairment of } \\
\text { entrusted loans }\end{array}$ & 0 & 0 & 0 & 0 \\
\hline + for inventories & $\begin{array}{c}8193593.4 \\
4 \\
\end{array}$ & $\begin{array}{c}10553167 . \\
04\end{array}$ & 10247232.53 & 5853674.88 \\
\hline $\begin{array}{c}+ \text { Bad debt } \\
\text { reserve }\end{array}$ & $\begin{array}{c}35875217 . \\
44\end{array}$ & $\begin{array}{c}14282830 . \\
91\end{array}$ & 14788925.27 & $\begin{array}{c}14497933.9 \\
9\end{array}$ \\
\hline $\begin{array}{l}=\text { net operating } \\
\text { profit after tax }\end{array}$ & $\begin{array}{c}194266093 \\
.6 \\
\end{array}$ & $\begin{array}{c}24062595 \\
4.1 \\
\end{array}$ & 324444111.7 & $\begin{array}{c}375627425 . \\
1\end{array}$ \\
\hline
\end{tabular}

According to the formula of investment capital, combined with China's annual report of SUPOR, the specific adjustment of the project and the calculation methods are as follows: 
(1) Interest bearing capital investment amount equal to the balance sheet of short-term borrowings, long-term loans due within one year, long-term loans and the total amount of bonds payable.

(2) The deferred tax credit equal to the deferred tax credit disclosure in the balance sheet.

(3) In advance of the reserves, is equal to the annual report of the asset impairment in the list of data.

(4) The current is not put into actual production assets, comprehensive annual report information, in this case refers to the construction project. ${ }^{[8]}$

TABLE II. TOTAL CAPITAL

\begin{tabular}{|c|c|c|c|c|}
\hline project & 2006 & 2007 & 2008 & 2009 \\
\hline $\begin{array}{c}\text { Common } \\
\text { shareholders' } \\
\text { equity }\end{array}$ & $\begin{array}{c}64075168 \\
7.82\end{array}$ & $\begin{array}{c}163333995 \\
5.88\end{array}$ & $\begin{array}{c}1930606743 \\
.65\end{array}$ & $\begin{array}{c}214961636 \\
2.61\end{array}$ \\
\hline $\begin{array}{c}\text { Minority } \\
\text { interests }\end{array}$ & $\begin{array}{c}13245585 \\
5.14\end{array}$ & $\begin{array}{c}174105621 \\
.23 \\
\end{array}$ & $\begin{array}{c}232018173 . \\
17\end{array}$ & $\begin{array}{c}237412232 . \\
76\end{array}$ \\
\hline + for inventories & $\begin{array}{c}8193593.4 \\
4\end{array}$ & $\begin{array}{c}10553167 . \\
04\end{array}$ & $\begin{array}{c}10247232.5 \\
3 \\
\end{array}$ & 5853674.88 \\
\hline $\begin{array}{l}\text { +Bad debt } \\
\text { reserve }\end{array}$ & $\begin{array}{c}35875217 \\
44\end{array}$ & $\begin{array}{l}14282830 . \\
91\end{array}$ & $\begin{array}{c}14788925.2 \\
7\end{array}$ & $\begin{array}{c}14497933.9 \\
9\end{array}$ \\
\hline $\begin{array}{l}\text { +Impairment of } \\
\text { fixed assets }\end{array}$ & 0 & 0 & 0 & 0 \\
\hline $\begin{array}{l}\text { +Short term } \\
\text { loan }\end{array}$ & $\begin{array}{l}29800000 \\
0.00\end{array}$ & $\begin{array}{c}8000000.0 \\
0\end{array}$ & 0 & 0 \\
\hline+ Long term loan & 120000.00 & 0 & 0 & 0 \\
\hline $\begin{array}{c}\text { +Long-term } \\
\text { borrowings due } \\
\text { within one year }\end{array}$ & 0 & 0 & 0 & 0 \\
\hline -building works & $\begin{array}{c}2256444.5 \\
8\end{array}$ & $\begin{array}{c}13922115 . \\
26\end{array}$ & $\begin{array}{c}58320879.0 \\
2\end{array}$ & $\begin{array}{c}41020320.8 \\
7\end{array}$ \\
\hline$=$ total capital & $\begin{array}{c}11131399 \\
09.26\end{array}$ & $\begin{array}{c}182635945 \\
9.8\end{array}$ & $\begin{array}{c}2129340195 \\
.60\end{array}$ & $\begin{array}{c}236635988 \\
3.4\end{array}$ \\
\hline
\end{tabular}

Debt capital $=$ short term borrowings + longterm borrowings + longterm borrowings due within one year

Equity capital $=$ total capital-debt capital

TABLE III. WEIGHTED AVERAGE COST OF CAPITAL

\begin{tabular}{|l|c|c|c|c|}
\hline \multicolumn{1}{|c|}{ project } & $\mathbf{2 0 0 6}$ & $\mathbf{2 0 0 7}$ & $\mathbf{2 0 0 8}$ & $\mathbf{2 0 0 9}$ \\
\hline $\begin{array}{l}\text { Total } \\
\text { capital }\end{array}$ & $\begin{array}{c}11313990 \\
9.26\end{array}$ & $\begin{array}{c}1826359459 . \\
8\end{array}$ & $\begin{array}{c}2129340195 \\
60\end{array}$ & $\begin{array}{c}2366359883 \\
4\end{array}$ \\
\hline $\begin{array}{l}\text { Debt } \\
\text { capital }\end{array}$ & $\begin{array}{c}298120000 \\
00\end{array}$ & 8000000.00 & 0 & 0 \\
\hline $\begin{array}{l}\text { equity } \\
\text { capital }\end{array}$ & $\begin{array}{c}815019909 . \\
26\end{array}$ & 1818359460 & 2129340195. & 2366359883 \\
\hline $\begin{array}{l}\text { Debt } \\
\text { capital } \\
\text { ratio }\end{array}$ & $26.79 \%$ & $0.44 \%$ & 00 & 0 \\
\hline $\begin{array}{l}\text { Proportion } \\
\text { of equity } \\
\text { capital }\end{array}$ & $73.27 \%$ & $99.52 \%$ & $100 \%$ & $100 \%$ \\
\hline
\end{tabular}

\begin{tabular}{|l|c|c|c|c|}
\hline project & $\mathbf{2 0 0 6}$ & $\mathbf{2 0 0 7}$ & $\mathbf{2 0 0 8}$ & $\mathbf{2 0 0 9}$ \\
\hline One-year loan interest rate & $5.85 \%$ & $5.85 \%$ & $5.85 \%$ & $5.85 \%$ \\
\hline Income tax rate & $33 \%$ & $33 \%$ & $25 \%$ & $25 \%$ \\
\hline Debt capital cost & $3.57 \%$ & $3.57 \%$ & $4.19 \%$ & $4.19 \%$ \\
\hline
\end{tabular}

\begin{tabular}{|l|c|c|c|c|}
\hline project & 2006 & 2007 & 2008 & 2009 \\
\hline Net profit & 1022104 & 1719395 & 2365069 & 3104167 \\
& 16.76 & 98.55 & 90.96 & 56.65 \\
\hline Income tax & 1604686 & 2688362 & 4700802 & 7198400 \\
& 0.81 & 1.22 & 6.57 & 0.70 \\
\hline
\end{tabular}

\begin{tabular}{|c|c|c|c|c|}
\hline \multicolumn{5}{|c|}{ TABLE III, cont. } \\
\hline Average income tax rate & $33 \%$ & $33 \%$ & $25 \%$ & $25 \%$ \\
\hline $\begin{array}{l}\text { Common stock rights and } \\
\text { interests }\end{array}$ & $\begin{array}{c}6407516 \\
87.82\end{array}$ & $\begin{array}{c}1633339 \\
955.88\end{array}$ & $\begin{array}{c}1930606 \\
743.65\end{array}$ & $\begin{array}{c}2149616 \\
362.61\end{array}$ \\
\hline Cost of equity capital & $12.36 \%$ & $8.16 \%$ & $11.01 \%$ & $13.34 \%$ \\
\hline project & 2006 & 2007 & 2008 & 2009 \\
\hline Debt capital ratio & $26.79 \%$ & $0.44 \%$ & 0 & 0 \\
\hline Debt capital cost & $3.57 \%$ & $3.57 \%$ & $4.19 \%$ & $4.19 \%$ \\
\hline Proportion of equity capital & $73.27 \%$ & $99.52 \%$ & $100 \%$ & $100 \%$ \\
\hline Cost of equity capital & $12.36 \%$ & $8.16 \%$ & $11.01 \%$ & $13.34 \%$ \\
\hline $\begin{array}{l}\text { Weighted average cost of } \\
\text { capital }\end{array}$ & $10.01 \%$ & $8.14 \%$ & $11.01 \%$ & $13.34 \%$ \\
\hline
\end{tabular}

TABLE IV. CAlculated EVA value

\begin{tabular}{|l|c|c|c|c|}
\hline project & $\mathbf{2 0 0 6}$ & $\mathbf{2 0 0 7}$ & $\mathbf{2 0 0 8}$ & $\mathbf{2 0 0 9}$ \\
\hline NOPAT & 194266093.6 & 240625954.1 & 324444111.7 & 375627425.1 \\
\hline WACC & $10.01 \%$ & $8.14 \%$ & $11.01 \%$ & $13.34 \%$ \\
\hline IC & 1113139909 & 1826359459 & 2129340195 & 2366359883 \\
\hline EVA & 82840788.68 & 91960294.07 & 90003756.16 & 59955016.66 \\
\hline
\end{tabular}

C. Value evaluation of SUPOR

Use formula

$$
V=I C+\sum_{t=1}^{\infty} \frac{E V A_{t}}{(1+\mathrm{r})^{t}}+\frac{E V A_{n}}{\mathrm{r}(1+r)^{t}}
$$

Calculate the value of SUPOR:

$$
\begin{aligned}
& V=1113139909.26+\frac{82840788.68}{1+10.01 \%}+\frac{91960294.07}{(1+8.14 \%)^{2}}+\frac{90003756.16}{(1+11.01 \%)^{3}} \\
& +\frac{59955016.66}{13.34 \%(1+13.34 \%)^{4}}=1605272946
\end{aligned}
$$

And then calculate the value of each share by the total shares: $1605272946 / 176,020,000.0=9.11$.

\section{CONCLUSION}

\section{A. Ignore channel value, theory is low}

In most cases, the actual valuation of enterprises tend to ignore or neglect the enterprise is the potential value of the channel, especially the asset sales channels, large errors will be on the target enterprise value assessment, theory should be far less than the actual value. Continue to strengthen cooperation with foreign enterprises of China's enterprises, domestic enterprises are also emerging channel based mergers and acquisitions, equity and other operations, which requires a reasonable assessment of the respective channels, and the current marketing practice is not a reasonable measure recognized, mostly the experience of corporate decision makers based on estimates, it can be said that there is a need to study the industry wide channel value; in the enterprise, channel as a special asset, can be a manager in charge of management. ${ }^{[9]}$

\section{B. Consider the synergy effect, the actual higher}

The use of EVA valuation model calculated at the beginning of 2006 per share value of 9.11 yuan calculation results, compared with the actual price, especially with the French company SEB acquisition of SUPOR shares before signing a cooperation agreement that: at the beginning of 2006, SUPOR's share price is only 7 yuan per share, to May 12 th to 
$\$ 9.3$ per share, consistent with the author EVA valuation model calculation results show that EVA Effective Valuation model. For the acquisition of a cooperation agreement in the actual operation, SEB company's share price of 18 yuan acquisition agreement, SUPOR group $\mathrm{Su}$ family shares and private placement of shares in SUPOR, and the SEB group was given the price of 47 yuan per share, launched a tender offer, so, calculate the EVA valuation model value was significantly lower than the purchase price the situation. ${ }^{[10]}$

In summary, SEB's acquisition of SUPOR stock price and its performance in the capital market prices are closely related, but the intrinsic value of the former two companies are not necessarily the same, EVA evaluation model based on the value of the calculation is in full consideration of the cost of capital and future discounted cash flow factors, the intrinsic value of the enterprise that occurred extreme changes in the market, and the stock price may deviate from it, but it does not mean EVA valuation model is invalid.

\section{REFERENCES}

[1] Chen Yufei. The application of target enterprise value evaluation method in enterprise M \& a [D]. Shaanxi University of Science and Technology, 2014

[2] Wu Xiangchun. Value evaluation of target enterprise in $M$ \& a [D]. Xiangtan University, 2014

[3] Zang Haiyan. Shandong Agricultural University research model to assess the value of [D]. in strategic corporate mergers and acquisitions, 2013

[4] Li. [D]. fruit Hebei University of Economics and Business research technique evaluation of target enterprises in strategic merger value, 2014

[5] Xie min. The acquisition target enterprise value evaluation of [D]. Central University of Finance and Economics, 2008

[6] Wang Rui. Research on the value evaluation of target enterprises in the merger and acquisition of the Ministry of finance, Ministry of finance, Fiscal Science Research Institute, 2012,

[7] Liu Chanjuan. Study on the value evaluation of target enterprise in M \& a [D]. Capital University of Economics and Business, 2008

[8] Hong Pan. Research on the basic theory of channel assets [D]. Jilin University, 2010

[9] Tang Hua. Study on the influence of channel assets on enterprise performance based on the view of resources [D]. Jilin University, 2010

[10] Chen Qijie, Liu Liu. Research on the measurement of channel relationship value based on the perspective of assets [J]. financial research, 2006 